\title{
Management of inflammatory bowel disease in pregnancy
}

\author{
M A Smith MA MRCP and J D Sanderson MD FRCP
}

Department of Gastroenterology, Guy's \& St Thomas' NHS Foundation Trust, London, UK

\begin{abstract}
Summary: Inflammatory bowel disease (IBD) affects body image, relationships, family planning, fertility and pregnancy outcomes. However, the common misconception that IBD is a contraindication, or serious concern, in pregnancy is essentially a myth. Most patients with IBD can expect to have uneventful pregnancies. We present an overview of the management of IBD during pregnancy, including management in those planning pregnancy, the suitability of relevant medication during pregnancy and breast feeding, investigation and monitoring of IBD during pregnancy, surgical management and considerations relating to delivery. While there are some definite alterations required in the management of IBD during pregnancy, management is essentially unchanged. With close attention to aspects such as nutrition and smoking cessation, and optimal disease control in the run-up to and during pregnancy, we have an opportunity to help our patients with IBD achieve good pregnancy outcomes.
\end{abstract}

Keywords: inflammatory bowel disease, Crohn's disease, ulcerative colitis, pregnancy, lactation

\section{INTRODUCTION}

The chronic inflammatory bowel diseases (IBDs) such as Crohn's disease (CD) and ulcerative colitis (UC) are predominantly diseases of young adults. In addition to the well-recognized significant morbidity, poor quality of life and occupational loss experienced by patients, IBD affects body image, relationships, family planning, fertility and pregnancy outcomes.

Historically, IBD and pregnancy have been considered a bad combination. Even as recently as the 1980s, a high proportion of women with IBD were being advised to avoid or even terminate pregnancy by their physicians. ${ }^{1}$ Although this is no longer the case, there is contemporary evidence that women with IBD still have serious misconceptions both about their ability to conceive and the risks of doing so for their own health and that of their child. ${ }^{2}$

Studies consistently demonstrate that women with IBD deliver smaller babies at an earlier gestational age than the general population. ${ }^{3}$ It should be stressed, however, that in general this is a statistical rather than a clinical issue, with the vast majority of pregnancies resulting in a good neonatal outcome. ${ }^{4}$ The literature generally agrees that good disease control is the key to success. Those with active disease, hospitalization and surgery during their pregnancy are at an increased risk of adverse outcomes in most series. ${ }^{5}$ Poor disease control at the time of conception has also been considered to predict ongoing disease activity and adverse pregnancy outcomes. ${ }^{6}$ However, some recent series have challenged the accepted wisdom that the risks of adverse pregnancy outcome was solely related to active disease, demonstrating that even those

Correspondence to: Dr Jeremy Sanderson, Department of Gastroenterology, 1st Floor, College House, St Thomas' Hospital, Lambeth Palace Road, London SE1 7EH, UK Email: jeremy.sanderson@kcl.ac.uk with excellent disease control were at an increased risk of complications when compared with the general population. ${ }^{7}$

The therapeutic approach to IBD, in particular CD, has become increasingly aggressive over recent years. Symptom control is no longer considered an adequate endpoint and emphasis is instead placed on mucosal healing and altered natural history, particularly the avoidance of surgery and other disease complications. While this approach improves patient outcomes, it necessitates increased investigation and drug exposure, with their attendant risks. During pregnancy this becomes an even more delicate balance.

\section{PREPARATION FOR PREGNANCY}

Prior knowledge that individuals with IBD are planning pregnancy provides a window of opportunity to help achieve a good outcome by optimizing disease management in the run up to conception.

Nutrition is of course important for all pregnancies but is a particular problem for IBD patients. IBD and its treatments can create specific (e.g. B12 deficiency) or more general malabsorption syndromes (protein and fat malabsorption, low iron and folate status and other nutrient deficiencies). Structural changes, whether caused directly by the disease or created surgically, can compound this. Food avoidance and intolerance is common, as is altered appetite, resulting in dietary deficiencies. Protein-calorie malnutrition is well documented in patients with IBD during pregnancy ${ }^{8}$ and poor maternal weight gain is associated with low birth weight and fetal growth restriction (FGR). ${ }^{9}$ Nutrition should therefore be optimized prior to conception with specific deficiencies sought and treated. Folate supplementation is particularly important and high dose (e.g. $5 \mathrm{mg}$ once daily) supplementation should be considered, as, in addition to the possibility of baseline deficiency, both pregnancy and IBD increase folate demand. 
Smoking cessation should be encouraged and support provided where necessary. In $C D$, the importance of this is paramount as, in addition to its deleterious effect in pregnancy, smoking is the strongest risk factor for increased disease activity and relapse, which are also related to low birth weights. In this respect, smoking cessation has been shown to account for the improvement in disease activity seen during pregnancy in some series. ${ }^{10}$ Smoking is also an additional risk factor for venous thromboembolism (VTE), associated with both IBD and pregnancy. ${ }^{8}$ Passive smoking in the neonate is also thought to increase the risk of developing IBD in later life, ${ }^{11}$ in addition to its other well-documented risks.

The importance of conception during remission and of good disease control during pregnancy has already been emphasized. If pregnancy is being planned, it provides an opportunity for the accurate assessment of disease activity and optimization of treatment where appropriate. If colonoscopy or computed tomography (CT) scanning are indicated, then, once again, there is a window of opportunity prior to conception which can be exploited. If the patient is likely to come to surgery in the near future then it may be better to bring this forward rather than delay and risk problems during the pregnancy itself. Pelvic surgery may be an exception to this, as it has an impact on fertility and fecundity. ${ }^{12}$

The importance of disease control must be emphasized to women who are naturally wary of being on medication during pregnancy. The evidence for the safety of the relevant medication can be discussed. This is reviewed below and summarized in Table 1. Importantly, patients who have been on methotrexate or mycophenolate should stop this for at least three months before they attempt to conceive, and receive highdose folate supplementation. Sulphasalazine (SASP) is also a folate antagonist, and patients receiving SASP therapy should also receive high-dose folate supplementation in the run up to conception. (Male patients who wish to start a family while established on SASP treatment should be counselled that it causes reversible oligospermia and be switched to an alternative agent.)

\section{MONITORING/INVESTIGATION}

The investigation of IBD during pregnancy is essentially little different from usual, although there is inevitably more emphasis placed on managing new symptoms, where possible, without an immediate recourse to invasive investigations. Patients should be monitored more closely than usual during pregnancy, with regular trips to obstetric medical/gastroenterology clinics. It is important that any relapse or complication is detected and treated early to ensure the best outcome for the mother and her pregnancy.

Blood monitoring is routinely used in clinic, although practitioners must be aware that it is normal for both haemoglobin and albumin to be lower in pregnancy. However, measures of iron and haematinics are unaffected. C-reactive protein remains a valid inflammatory parameter but the erythrocyte sedimentation rate is elevated by pregnancy itself and may be misleading.

Endoscopic investigation may be used, where essential, during pregnancy. There is a substantial body of evidence that flexible sigmoidoscopy is safe, although colonoscopy is generally avoided if possible. ${ }^{5}$ Where invasive investigation cannot be deferred until after delivery, the second trimester is considered to be the safest time for such procedures to be performed. However, where urgent assessment is required, endoscopy may be used, with caution, at any time.

Abdominal X-ray investigations should be used only when absolutely necessary during pregnancy. Where possible, CT should be avoided, but MRI and ultrasound are safe. ${ }^{5}$ When essential, for example to look for colonic dilation in acute severe colitis, X-rays can be used, as the risk to mother and fetus of incomplete assessment is considerable.

\section{TREATMENT OF IBD DURING PREGNANCY}

Below is an overview of the literature relating to the main treatments for IBD during pregnancy, Table 1 provides a summary. The definitions of Food and Drug Administration (FDA) categories are shown in Table 2. Essentially the indications for each treatment are unaffected by pregnancy, with the exception of methotrexate and mycophenolate, which are contraindicated. While understanding that women are wary of taking medication during pregnancy, in general, the risks associated with active disease outweigh those of continued treatment, and most women should be reassured about the safety profiles of their drugs and encouraged to continue taking them. Some individuals experience fewer problems from their IBD during pregnancy, an effect that may be dependent on the mother and baby having differing HLA profiles, ${ }^{13}$ and has also been linked to smoking cessation. ${ }^{10}$ Alternatively the occurrence of the pregnancy at this time could be a marker that the individual is in relatively good health and experiencing better disease control. In other series higher rates of relapse in the first trimester have been associated with medication cessation, and overall relapse rates tend to be the same as over any other nine-month period. ${ }^{14,15}$ Pregnancy may have a beneficial effect on the course of IBD in the long term with two studies suggesting improved outcomes in the years after pregnancy, with fewer disease flares and a reduced requirement for surgery. ${ }^{16,17}$

\section{5-Aminosalicylates}

SASP and the more commonly used aminosalicylates (5-ASAs) predominantly act topically in the area of gut to which they are targeted by their formulation. Their main role is in the maintenance of remission in UC or at higher doses for remission induction. The efficacy of 5-ASAs in CD is debatable with high numbers needed to treat reducing their use. With the possible exception of olsalazine, these drugs are considered safe in pregnancy and should be continued in patients for whom they have provided a good outcome. A possible association with increased risk of pregnancy loss and preterm delivery is thought to be due to the confounding effect of active disease and co-prescription of steroids. ${ }^{18}$

\section{Steroids}

As with many other chronic inflammatory conditions, a key treatment goal in IBD is to reduce steroid exposure, to avoid both short- and long-term toxicity. Nonetheless, corticosteroids remain an important and effective means of achieving a rapid remission. Maternal toxicity such as hypertension, osteoporosis and impaired glucose tolerance are of particular 
Table 1 Summary of the suitability of medication used in the treatment of inflammatory bowel disease during pregnancy

\begin{tabular}{|c|c|c|c|c|c|c|c|}
\hline Drug & $\begin{array}{l}\text { Crosses } \\
\text { placenta? }\end{array}$ & $\begin{array}{l}\text { Evidence of harm } \\
\text { in animals? }\end{array}$ & $\begin{array}{l}\text { Congenital } \\
\text { abnormality in } \\
\text { humans? }\end{array}$ & $\begin{array}{l}\text { Adverse } \\
\text { pregnancy } \\
\text { outcome? }\end{array}$ & $\begin{array}{l}\text { Harm to } \\
\text { mother? }\end{array}$ & $\begin{array}{l}\text { FDA } \\
\text { category }\end{array}$ & Advice \\
\hline $\begin{array}{l}\text { Prednisolone } \\
\text { prednisone } \\
\text { hydrocortisone }\end{array}$ & $\begin{array}{l}\text { Low levels - } \\
\text { metabolized by } \\
\text { placental } \\
\text { enzymes }\end{array}$ & Yes & $\begin{array}{l}\text { Possible link to cleft } \\
\text { palate not } \\
\text { confirmed }\end{array}$ & $\begin{array}{l}\text { Preterm, PROM, } \\
\text { fetal growth } \\
\text { restriction }\end{array}$ & $\begin{array}{l}\text { Hypertension, } \\
\text { diabetes, } \\
\text { infection, } \\
\text { osteoporosis }\end{array}$ & $\mathrm{C}$ & $\begin{array}{l}\text { Supplement calcium. } \\
\text { Give 'stress dose' } \\
\text { at delivery }\end{array}$ \\
\hline Budesonide & Yes & $\begin{array}{l}\text { Yes, high dose } \\
\text { sub-cutaneously } \\
\text { was teratogenic }\end{array}$ & None reported & None reported & None reported & C & $\begin{array}{l}\text { Limited data with } \\
\text { only one case } \\
\text { series in IBD, but } \\
\text { appears safe }\end{array}$ \\
\hline $\begin{array}{l}\text { Dexamethasone } \\
\text { betamethasone }\end{array}$ & $\begin{array}{l}\text { Yes - and not well } \\
\text { metabolized by } \\
\text { placental } \\
\text { enzymes } \\
\text { increasing fetal } \\
\text { exposure }\end{array}$ & $\begin{array}{l}\text { Yes - } \\
\text { neurodevelopmental } \\
\text { abnormalities }\end{array}$ & $\begin{array}{l}\text { Neurodevelopmental } \\
\text { abnormalities }\end{array}$ & $\begin{array}{l}\text { Preterm, PROM, } \\
\text { fetal growth } \\
\text { restriction }\end{array}$ & $\begin{array}{l}\text { Hypertension, } \\
\text { diabetes, } \\
\text { infection, } \\
\text { osteoporosis }\end{array}$ & C & $\begin{array}{l}\text { Use alternative } \\
\text { steroid agent }\end{array}$ \\
\hline $\begin{array}{l}\text { 5-ASA (except } \\
\text { olsalazine) }\end{array}$ & Low levels & No & No & $\begin{array}{l}\text { Preterm, low } \\
\text { birthweight } \\
\text { (?confounded by } \\
\text { disease activity), } \\
1 \text { case of renal } \\
\text { insufficiency in } \\
\text { neonate }\end{array}$ & No & B & $\begin{array}{l}\text { Use considered safe } \\
\text { where necessary, } \\
\text { avoid doses } \\
\text { greater than } \\
3 \mathrm{~g} / \text { day due to } \\
\text { risk of fetal } \\
\text { nephrotoxicity }\end{array}$ \\
\hline Olsalazine & Low levels & Yes - at high doses & Inadequate data & Inadequate data & None reported & C & $\begin{array}{l}\text { Use alternative } \\
\text { 5-ASA }\end{array}$ \\
\hline Sulphasalazine & Yes & No & $\begin{array}{l}\text { Case reports but } \\
\text { literature overall } \\
\text { against association }\end{array}$ & $\begin{array}{l}\text { Folic acid } \\
\text { antagonist, case } \\
\text { reports of } \\
\text { myelotoxicity at } \\
\text { high maternal } \\
\text { doses }(>2 \mathrm{~g})\end{array}$ & No & B & $\begin{array}{l}\text { High dose folic acid } \\
\text { supplementation } \\
\text { (5 mg once daily) }\end{array}$ \\
\hline $\begin{array}{l}\text { Azathioprine/ } \\
6 \mathrm{MP}\end{array}$ & Yes & $\begin{array}{l}\text { Yes - congenital } \\
\text { abnormalties in } \\
\text { some species }\end{array}$ & $\begin{array}{l}\text { Possible association } \\
\text { in transplant } \\
\text { cohorts, no } \\
\text { association in IBD } \\
\text { cohorts }\end{array}$ & $\begin{array}{l}\text { Possible } \\
\text { association with } \\
\text { preterm delivery. } \\
\text { Transplant } \\
\text { cohorts had fetal } \\
\text { growth } \\
\text { restriction, } \\
\text { probably due to } \\
\text { steroid } \\
\text { co-prescription. } \\
\text { Case reports of } \\
\text { neonatal } \\
\text { myelotoxicity }\end{array}$ & No & D & $\begin{array}{l}\text { Likely to be safe. } \\
\text { Acceptable for use } \\
\text { in pregnancy. } \\
\text { Azathioprine } \\
\text { preferable to } 6 \mathrm{MP} \\
\text { as fetus cannot } \\
\text { convert to } 6 \mathrm{MP} \\
\text { and is therefore } \\
\text { less exposed to } \\
\text { the active } \\
\text { metabolites. Be } \\
\text { aware of risk of } \\
\text { myelosuppression } \\
\text { in neonate }\end{array}$ \\
\hline Ciclosporin A & $\begin{array}{l}\text { Conflicting data, } \\
\text { probably low } \\
\text { levels }\end{array}$ & $\begin{array}{l}\text { Nephrotoxicity at high } \\
\text { doses }\end{array}$ & No & $\begin{array}{l}\text { Possible } \\
\text { association with } \\
\text { preterm delivery } \\
\text { and low birth } \\
\text { weight }\end{array}$ & $\begin{array}{l}\text { Theoretical risk } \\
\text { of } \\
\text { hypertension }\end{array}$ & C & $\begin{array}{l}\text { Limit use to } \\
\text { fulminant colitis }\end{array}$ \\
\hline Methotrexate & Yes & Yes & $\begin{array}{l}\text { Yes - multiple } \\
\text { associated } \\
\text { abnormalities }\end{array}$ & $\begin{array}{l}\text { Increased } \\
\text { pregnancy loss }\end{array}$ & No & $x$ & Avoid \\
\hline $\begin{array}{l}\text { Mycophenelate } \\
\text { mofetil }\end{array}$ & Yes & Yes & $\begin{array}{l}\text { Case reports of } \\
\text { multiple } \\
\text { abnormalities, } \\
\text { limited literature }\end{array}$ & $\begin{array}{l}\text { Increased } \\
\text { pregnancy loss }\end{array}$ & No & C & $\begin{array}{l}\text { Avoid - other agents } \\
\text { are preferred }\end{array}$ \\
\hline Infliximab & $\begin{array}{l}\text { In the third } \\
\text { trimester only }\end{array}$ & No & $\begin{array}{l}\text { Possible association } \\
\text { with VACTERL } \\
\text { abnormalities } \\
\text { although this was } \\
\text { not confirmed in } \\
\text { the large TREAT } \\
\text { registry }\end{array}$ & No & No & B & $\begin{array}{l}\text { Likely to be safe. Use } \\
\text { where benefits are } \\
\text { deemed to } \\
\text { outweigh risks. Try } \\
\text { to avoid use in the } \\
\text { third trimester. } \\
\text { Avoid live vaccines } \\
\text { in the newborn } \\
\text { before } 6 \text { months of } \\
\text { age }\end{array}$ \\
\hline Adalimumab & Unknown & No & $\begin{array}{l}\text { Possible association } \\
\text { in rheumatology } \\
\text { cohorts }\end{array}$ & $\begin{array}{l}\text { Case reports in } \\
\text { IBD have all } \\
\text { been fine }\end{array}$ & No & B & $\begin{array}{l}\text { Not enough evidence } \\
\text { to conclude at } \\
\text { present time }\end{array}$ \\
\hline
\end{tabular}

FDA = Food and Drug Administration; PROM = preterm rupture of the membrane; IBD = inflammatory bowel disease; $A S A=$ aminosalicylate; $6 \mathrm{MP}=6$-mercaptopurine 


\begin{tabular}{ll}
$\begin{array}{l}\text { Table } 2 \text { Summary of the FDA categories for medications in } \\
\text { pregnancy }\end{array}$ \\
\hline $\begin{array}{l}\text { FDA } \\
\text { category }\end{array}$ \\
\hline A & $\begin{array}{c}\text { Controlled studies in animals and women fail to show fetal } \\
\text { risk } \\
\text { Either animal studies show no risk and no data in women, or } \\
\text { animal studies show an adverse effect that has not been } \\
\text { confirmed in controlled studies of women in their first } \\
\text { trimester }\end{array}$ \\
C & $\begin{array}{c}\text { No controlled studies available in women, and either animal } \\
\text { studies not done or done and showed an adverse effect } \\
\text { Evidence of risk to the fetus but benefits may still outweigh } \\
\text { this risk }\end{array}$ \\
D & $\begin{array}{c}\text { Evidence of risk to the fetus and drug contraindicated in } \\
\text { pregnancy }\end{array}$ \\
X & Not rated \\
NR &
\end{tabular}

$\mathrm{FDA}=$ Food and Drug Administration

concern as they are problems already associated with pregnancy. Although some studies have suggested that steroids are associated with an increased risk of cleft lip and palate, when prescribed in the first trimester, ${ }^{19}$ this is refuted by others. $^{20}$ The benefit of disease control probably outweighs any risk. Administration later in pregnancy has been associated with FGR, preterm rupture of the membranes and preterm delivery. ${ }^{19}$ Where prescription of steroids cannot be avoided (for example in a severe flare of $\mathrm{UC}$ ), prednisolone or hydrocortisone should be used rather than fluorinated steroids such as dexamethasone and betamethasone, which are less metabolized by the placenta and therefore increase fetal exposure. ${ }^{19}$ Budesonide has limited data in pregnancy but would be predicted to be associated with less maternal toxicity and early data are encouraging. ${ }^{21}$ In those patients who have been on long-term steroid therapy a double 'stress dose' should be given at the time of delivery or for those on greater than $7.5 \mathrm{mg}$, parenteral hydrocortisone administered.

\section{Thiopurines}

Immunomodulatory treatments, in particular the thiopurines (azathioprine $[\mathrm{AZA}]$ and 6-mercaptopurine $[6 \mathrm{MP}]$ ) remain the cornerstone of IBD management, with proven efficacy in reducing relapses, permitting steroid withdrawal and closing fistulas. Indeed, as many as $60 \%$ of patients with $C D$ now receive AZA or $6 \mathrm{MP}$ at some point in their disease course. Although manufacturers suggest avoiding these agents in pregnancy, there is a growing body of literature suggesting that thiopurine therapies can be safely used in this context. ${ }^{22}$ AZA may be preferable as the fetus lacks the ability to convert this to $6 \mathrm{MP}$, theoretically reducing exposure to active metabolites. Metabolite monitoring may help to ensure optimal dosing, which in this context could avoid unnecessary over-exposure of the fetus, in addition to under-dosing and relapse. There are rare reports of the neonatal myelotoxicity from maternal administration of thiopurines and clinicians should be alert to this possibility. ${ }^{23}$ Where the mother is known to have heterozygous thiopurine methyl transferase (TPMT) deficiency, particular care should be taken, as the baby has a one in 40 chance of having no active TPMT, rendering them exquisitely sensitive to thiopurine drugs.

\section{Methotrexate}

Methotrexate, originally developed as an abortifacient, is associated with increased pregnancy loss and a large number of congenital abnormalities. It is FDA category $\mathrm{X}$ and should be avoided in pregnancy. Patients on methotrexate should be advised to use two forms of contraception and be off methotrexate for at least three months before they attempt to conceive. As methotrexate is a folate antagonist, patients who have recently been using methotrexate should receive high dose folate supplementation. Patients inadvertently exposed to methotrexate during early pregnancy should stop the drug immediately and be counselled of these risks. The risk of malformation has been estimated to fall between $9 \%$ and $33 \%$ in this context.

\section{Ciclosporin A}

There are several reports in the literature of the use of ciclosporin A (CyA) for fulminant colitis in pregnancy. Results have been encouraging, with high remission rates achieved. There is a single report of nephrotoxicity in the newborn. Evidence from the transplant literature suggests a possible link with preterm delivery. Theoretical concerns that CyA would be associated with maternal hypertension have not been substantiated, although blood pressure should be carefully monitored. For this single indication therefore, CyA can be used in pregnant patients.

\section{Mycophenolate mofetil}

There are limited data available for mycophenolate in pregnancy and concerns raised by animal studies plus reports of malformations in humans have led to the recommendation that it be avoided in pregnancy.

\section{Biologics}

Infliximab is a chimeric anti-tumour necrosis factor (TNF)- $\alpha$ antibody with established efficacy in the treatment of moderate to severe refractory $\mathrm{CD}$ and an emerging role in UC. Adalimumab is a fully humanized anti-TNF- $\alpha$ antibody of equivalent efficacy, used as a first- or second-line alternative to infliximab. While most reviewers conclude that there are insufficient data to recommend the use of biologics in pregnancy, in practice this can be unavoidable for patients with severe refractory disease. Furthermore, the available data are, on the whole, reassuring. Concerns that there could be a VACTERL (Vertebral, Anal, Cardiac, Tracheo-oesophageal, Renal and Limb anomalies) association with TNF antagonists were raised after analysing all reports of congenital abnormalities to the FDA, ${ }^{24}$ but this has not been borne out in the TREAT registry ${ }^{25}$ or other large series. ${ }^{26}$ Immunoglobulins are known to cross the placenta in the third trimester, and therefore, where possible, dosing should be timed to avoid administration of biologics during this phase. Where neonates have been exposed to biologics during the last trimester, administration of live vaccines should be avoided. Detectable infliximab in the neonate has been documented up to six months of age. ${ }^{27}$

In practice, most women becoming pregnant while on biologics have probably gained a precious remission using such agents and the risk:benefit balance almost certainly falls strongly in favour of continuing treatment. 


\section{Surgery}

As for medical treatment, the indications for surgery in the management of IBD are essentially unchanged by pregnancy. Emergency management, for example to deal with a toxic megacolon, perforation or obstruction must proceed and if the pregnancy is approaching term then caesarean section has frequently been performed during the same procedure. ${ }^{28}$ There are many reports in the literature of this resulting in a good outcome for both mother and baby. However, on the whole, recourse to surgery during pregnancy is associated with preterm delivery and pregnancy loss. How much of this is attributable to the surgery itself and how much to the underlying complication necessitating surgery is not clear. This observation has meant that medical management is preferred, particularly where it may buy critical time for the fetus to mature. It should be emphasized however that surgery should not be ruled out altogether. In the general population routine surgery is considered essentially safe during pregnancy, and where clear advantages for surgical management exist, the short-term risk of surgery may be smaller than the ongoing risks associated with the underlying disease.

\section{Other treatment modalities}

Nutritional treatment is a safe alternative where there is a desire to avoid drug exposure, particularly steroids. There are reports of successful treatment of active CD in pregnancy by elemental diet alone. Antibiotics may be used in pregnancy but metronidazole is preferred to ciprofloxacin, which has been associated with arthropathy in animal studies. Anti-diarrhoeals may be used.

\section{Issues around delivery}

Patients with IBD are at increased risk of VTE. ${ }^{8}$ This is particularly true in the puerperium. Consideration should be given to thromboprophylaxis, particularly for those with additional risk factors for thrombosis, including caesarean section.

High rates of caesarean section have been repeatedly reported in IBD cohorts ${ }^{3}$ but the indications should generally remain the same as those for the non-IBD population with two possible exceptions:

\section{Peri-anal CD}

Those with active peri-anal CD at the time of delivery should have an elective caesarean section, as should those with significant scarring and fibrosis of the perineum. Spontaneous vaginal delivery (SVD) in other patients with CD does not appear to be associated with the development of new peri-anal disease or recurrence of inactive disease, and complication rates are the same as those in the general population. ${ }^{29}$

\section{Ileo-anal pouch anastomosis}

Patients with ileo-anal pouches have been the subject of particular interest regarding elective caesarean section. Pouch function does seem to worsen in the latter stages of pregnancy, probably due to local pressure effects; however, this returns to normal rapidly after delivery. Risks of SVD seem to be the same as those in the general population. However, caution has been advised in this group, as sphincter damage, shown to be a common occurrence during SVD, could have much more serious functional consequences. ${ }^{30}$

\section{BREAST FEEDING}

The benefits of breast feeding must be weighed against the risk to the baby of each agent and also the risk to the mother of treatment cessation, which has been shown to be associated with increased relapse rates in the puerperium. ${ }^{31}$ Drug manufacturers generally suggest avoiding breast feeding; however 5-ASAs, SASP, AZA, 6MP and infliximab are all likely to be safe. Thiopurine use during breast feeding is a frequent cause for debate. The literature shows no evidence of harm. Thiopurines are present at trace levels in breast milk and undetectable in the breast-fed babies. The available data for all agents are summarized in Table 3.

\section{SUMMARY}

While there are some definite alterations in practice required in the management of IBD in pregnancy, in general the approach is largely unchanged from normal. Some commonly held views are more myth than reality, and an informed, balanced

Table 3 Summary of the suitability of medication used in the treatment of inflammatory bowel disease during breast feeding

\begin{tabular}{|c|c|c|c|c|}
\hline Drug & Present in breast milk? & Level in baby & Evidence of harm? & Recommendations \\
\hline Steroids & Low levels & Unknown & No & $\begin{array}{l}\text { Safe up to } 40 \mathrm{mg} \text { prednisolone, at higher doses monitor } \\
\text { baby for adrenal suppression }\end{array}$ \\
\hline Budesonide & Yes & Unknown & Unknown & No data, but theoretically safe \\
\hline Sulphasalazine & Insignificant & Unknown & $\begin{array}{l}\text { Case report rash/diarrhoea, } \\
\text { theoretical risk of haemolysis }\end{array}$ & $\begin{array}{l}\text { Benefits likely to outweigh risk in those established on } \\
\text { treatment }\end{array}$ \\
\hline AZA/6MP & Yes & Undetectable & No & $\begin{array}{l}\text { Benefits likely to outweigh risk in those established on } \\
\text { treatment }\end{array}$ \\
\hline Mycophenolate & $\begin{array}{l}\text { Unknown - present in milk in } \\
\text { animal studies }\end{array}$ & Unknown & Unknown & Avoid \\
\hline Infliximab & In one patient & Undetectable & No & $\begin{array}{l}\text { Benefits likely to outweigh risk in those established on } \\
\text { treatment }\end{array}$ \\
\hline Adalimumab & Unknown & Unknown & Unknown & $\begin{array}{l}\text { Avoid - manufacturer advises against breast feeding } \\
\text { within five months }\end{array}$ \\
\hline
\end{tabular}

$\mathrm{ASA}=$ aminosalicylate; $6 \mathrm{MP}=6$-mercaptopurine; $\mathrm{AZA}=$ azathioprine; $\mathrm{CyA}=$ ciclosporin $\mathrm{A}$ 
approach, carefully weighing risks against benefits for each patient, should provide the best outcome.

\section{ADVICE SUMMARY}

Pre-pregnancy:

- Nutritional assessment and optimization;

- Test for and correct nutritional deficiencies;

- Folate supplementation (high dose $5 \mathrm{mg}$ once daily if nutritional inadequacies, recent methotrexate or SASP use or documented deficiency);

- Smoking cessation;

- Disease assessment and optimization;

- Explanation/discussion re risks and benefits of medication before pregnancy;

- Stop mycophenolate and methotrexate and replace with suitable alternative at least three months before conception.

Medication during pregnancy:

- With the exception of mycophenolate and methotrexate (see above) medication should continue, with indications unchanged from the non-pregnant state. Time infliximab infusions to avoid the last trimester when it crosses the placenta.

Surgery and investigation during pregnancy:

- Indications essentially unchanged;

- Avoid radiation exposure where possible;

- Defer surgery only when safe medical alternative exists.

Delivery:

- Most patients should be able to attempt a normal vaginal delivery;

- High risk for VTE;

- Indications for caesarean section are obstetric plus:

○ Active peri-anal disease;

o Ileo-anal pouch (not an absolute indication).

\section{REFERENCES}

1 Mayberry JF, Weterman IT. European survey of fertility and pregnancy in women with Crohn's disease: a case control study by European collaborative group. Gut 1986;27:821-5

2 Mountifield R, Bampton P, Prosser R, et al. Fear and fertility in inflammatory bowel disease: a mismatch of perception and reality affects family planning decisions. Inflamm Bowel Dis 2009;15:720-5

3 Cornish J, Tan E, Teare J, et al. A meta-analysis on the influence of inflammatory bowel disease on pregnancy. Gut 2007;56:830-7

4 Mahadevan U. Fertility and pregnancy in the patient with inflammatory bowel disease. Gut 2006;55:1198-206

5 Heetun ZS, Byrnes C, Neary P, et al. Review article: Reproduction in the patient with inflammatory bowel disease. Aliment Pharmacol Ther 2007;26:513-33

6 Norgard B, Hundborg HH, Jacobsen BA, et al. Disease activity in pregnant women with Crohn's disease and birth outcomes: a regional Danish cohort study. Am J Gastroenterol 2007;102:1947-54
7 Mahadevan U, Sandborn WJ, Li DK, et al. Pregnancy outcomes in women with inflammatory bowel disease: a large community-based study from Northern California. Gastroenterology 2007;133:1106-12

8 Nguyen GC, Boudreau H, Harris ML, et al. Outcomes of obstetric hospitalizations among women with inflammatory bowel disease in the United States. Clin Gastroenterol Hepatol 2009;7:329-34

9 Moser MA, Okun NB, Mayes DC, et al. Crohn's disease, pregnancy, and birth weight. Am J Gastroenterol 2000;95:1021-6

10 Agret F, Cosnes J, Hassani Z, et al. Impact of pregnancy on the clinical activity of Crohn's disease. Aliment Pharmacol Ther 2005;21:509-13

11 Lashner BA, Shaheen NJ, Hanauer SB, et al. Passive smoking is associated with an increased risk of developing inflammatory bowel disease in children. Am J Gastroenterol 1993;88:356-9

12 Hudson M, Flett G, Sinclair TS, et al. Fertility and pregnancy in inflammatory bowel disease. Int J Gynaecol Obstet 1997;58:229-37

13 Kane S, Kisiel J, Shih L, et al. HLA disparity determines disease activity through pregnancy in women with inflammatory bowel disease. Am J Gastroenterol 2004:99:1523-6

14 Nielsen OH, Andreasson B, Bondesen S, et al. Pregnancy in Crohn's disease. Scand J Gastroenterol 1984;19:724-32

15 Nielsen OH, Andreasson B, Bondesen S, et al. Pregnancy in ulcerative colitis Scand J Gastroenterol 1983;18:735-42

16 Nwokolo CU, Tan WC, Andrews HA, et al. Surgical resections in parous patients with distal ileal and colonic Crohn's disease. Gut 1994;35:220-3

17 Riis L, Vind I, Politi P, et al. Does pregnancy change the disease course? A study in a European cohort of patients with inflammatory bowel disease. Am J Gastroenterol 2006;101:1539-45

18 Norgard B, Fonager K, Pedersen L, et al. Birth outcome in women exposed to 5-aminosalicylic acid during pregnancy: a Danish cohort study. Gut 2003;52:243-7

19 Park-Wyllie L, Mazzotta P, Pastuszak A, et al. Birth defects after maternal exposure to corticosteroids: prospective cohort study and meta-analysis of epidemiological studies. Teratology 2000;62:385-92

20 Czeizel AE, Rockenbauer M. Population-based case-control study of teratogenic potential of corticosteroids. Teratology 1997;56:335-40

21 Beaulieu DB, Ananthakrishnan AN, Issa M, et al. Budesonide induction and maintenance therapy for Crohn's disease during pregnancy. Inflamm Bowel Dis 2009;15:25-8

22 Francella A, Dyan A, Bodian C, et al. The safety of 6-mercaptopurine for childbearing patients with inflammatory bowel disease: a retrospective cohort study. Gastroenterology 2003;124:9-17

23 Connell W, Miller A. Treating inflammatory bowel disease during pregnancy: risks and safety of drug therapy. Drug Saf 1999;21:311-23

24 Carter JD, Ladhani A, Ricca LR, et al. A safety assessment of tumor necrosis factor antagonists during pregnancy: a review of the Food and Drug Administration database. J Rheumatol 2009;36:635-41

25 Lichtenstein GR, Cohen RD, Feagan B, et al. Safety of infliximab in Crohn's disease: data from the 5000-patient TREAT registry. Gastroenterology 2004;126(Suppl.1):A54

26 Katz JA, Antoni C, Keenan GF, et al. Outcome of pregnancy in women receiving infliximab for the treatment of Crohn's disease and rheumatoid arthritis. Am J Gastroenterol 2004;99:2385-92

27 Vasiliauskas EA, Church JA, Silverman N, et al. Case report: evidence for transplacental transfer of maternally administered infliximab to the newborn. Clin Gastroenterol Hepatol 2006;4:1255-8

28 Hill J, Clark A, Scott NA. Surgical treatment of acute manifestations of Crohn's disease during pregnancy. J R Soc Med 1997;90:64-6

29 Ilnyckyj A, Blanchard JF, Rawsthorne P, et al. Perianal Crohn's disease and pregnancy: role of the mode of delivery. Am J Gastroenterol 1999;94:3274-8

30 Cornish JA, Tan E, Teare J, et al. The effect of restorative proctocolectomy on sexual function, urinary function, fertility, pregnancy and delivery: a systematic review. Dis Colon Rectum 2007;50:1128-38

31 Kane S, Lemieux N. The role of breastfeeding in postpartum disease activity in women with inflammatory bowel disease. Am J Gastroenterol 2005;100: 102-5

(Accepted 30 March 2010) 